\title{
TESES DE DOUTORADO E DISSERTAÇÕES DE MESTRADO DEFENDIDAS
}

(Janeiro à Outubro de 2002)

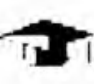 \\ Difusão de conhecimentos sobre o meio ambiente na indústria.}

Teses de Doutorado

\section{Elisabeth Zolcsak \\ (Orientador: Eduardo Yázigi)}

Para análise da difusão de conhecimentos sobre o meio ambiente na gestão ambiental da indústria esta tese toma em vista três modelos mentais de meio ambiente - o modelo acadêmico, o empresarial e o modelo do senso comum. Após conceituar estas representações mentais de meio ambiente e expor especificidades

\section{- Conexidade, Complexo Geográfico - Vidal de la Blache, Pierre Monbeig}

Aldo Aloisio Dantas da Silva (Orientadora: Iraci G. V Palheta)

Este trabalho discute a noção de conexidade, de Paul Vidal de la Blache, e a de complexo geográfico, de Pierre Monbeig. A idéia principal é a de que, para se compreender a concepção vidaliana de geografia, é fundamental compreender o contexto histórico, cultural e intelectual francês da última metade do século XIX e inicio do $X X$. Do mesmo modo, para se compreenderem melhor os trabalhos e as da proteção ambiental em empresas, apresenta um estudo de caso efetuado na empresa Unilever - Divisão Elida Gibbs, em Vinhedo, São Paulo.

Analisa o diálogo entre os modelos empresarial e do senso comum face ao conhecimento ecológico e discute que a educação ambiental, dos trabalhadores de uma empresa e de modo geral, deve se pautar em história natural e se desdobrar em uma educação para o planejamento ambiental visando incrementar a percepção judicativa e a capacidade de participação dos cidadãos na construção do espaço.

reflexões desenvolvidos por Monbeig, sobre a geografia, é necessário entenderse o momento em que ele foi formado, o contexto histórico cultural do Brasil, no momento de sua chegada e, principalmente, a realidade geográfica brasileira na década de 30. Paul Vidal de la Blache (1845-1918), geógrafo francês - fundador da Escola Francesa de Geografia -, para quem a geografia é uma ciência de sintese, que deve combinar sempre aspectos da natureza e da sociedade, interpreta as relações dos grupos humanos com a natureza a partir da elaboração dos conceitos de meio e de gênero de vida. Entende que os agrupamentos humanos, através do uso, humanizam a natureza e, 
imbricando-se com a plasticidade do globo, imprimem suas marcas na superfície da Terra produzindo paisagens. Essas paisagens são a materialidade e a expressão da realização das combinações (conexidades) entre elementos da natureza e da cultura. Para analisá-las, Vidal desenvolve, também, a demarche regional, fortemente alicerçado numa dialética das escalas. Monbeig é um geógrafo da geração do entre-guerras e chega ao Brasil trazendo

\section{O Desenvolvimento Sustentável - A Crise do Capital e o Processo de Recolonização}

\author{
Manoel Rebêlo Junior \\ (Orientador: Francisco C. Scarlato)
}

O objetivo deste trabalho é explicar o significado do chamado desenvolvimento sustentável. Para isso procurou entender o processo de produção, reprodução e apropriação do capital, visto como o

\section{- O espaço público nas áreas centrais: a rua como referência - um estudo de caso em Uberlândia - MG}

Willian Rodrigues Ferreira (Orientadora: Amália Inês de Lemos)

A ênfase em se abordar um tema de tese cujas reflexões e análises se pautam na relação entre o homem e o espaço nas áreas centrais, tendo a "rua" como referência, reflete uma preocupação, enquanto estudioso do espaço urbano, de uma bagagem simples, que os geógrafos naquele momento sabiam manejar: o trabalho de campo e o modelo de análise regional vidaliano, empobrecido pela chamada geografia clássica. Ao tentar aplicar o modelo regional à realidade brasileira, percebe as suas limitações, o que o leva a desenvolver - retomando as idéias originais de Vidal de la Blache e também as de André Cholley - a noção de complexo geográfico.

processo de produção, reprodução e apropriação da riqueza capitalista. Com a crise geral do capitalismo no início dos anos setenta e frente à reivindicação do Terceiro Mundo por uma nova ordem econômica mundial, o desenvolvimento sustentável aparece assim como uma reação dos países ricos para o que chama a "salvação do planeta" Possuindo uma mensagem com grande cunho humanitário, esconde na verdade uma agressiva política de recolonização.

um problema cada vez maior em nossas cidades, a perda gradativa dos espaços públicos de circulação para a convivência, os encontros e a recreação. Essa problemática urbana vem se acirrando há várias décadas, em função da depreciação acelerada desses ambientes ditos "comuns a todos", acompanhada da respectiva perda de sua função, ou inversão de funções, em conseqüência do processo de "esvaziamento do homem público" e do correspondente alargamento da esfera privada no meio urbano, acarretando um incentivo à busca cada vez mais acentua- 
da de espaços privados de consumo, lazer, cultura, práticas esportivas, como também respaldando o significativo avanço da iniciativa privada nas (re)adequações das formas espaciais públicas e sua respectiva "gestão" Esta pesquisa teve como objetivo avaliar as condições de uso atual do espaço público da rua nas áreas centrais, identificando as variáveis que acarretaram e acarretam sua depreciação acelerada e sua respectiva perda de função, para que se possam propor formas adequadas de aproveitamento e destinação desse espaço a toda a população. Observou-se que não há uma preocupação real em se criarem políticas públicas que possibilitem uma readequação dos espaços públicos nas áreas centrais, devolvendo-os a todos os cidadãos indistintamente, pois elas esbarram em prioridades que resguardam os valores dos grupos sociais de renda média e alta. Faz-se necessário, dessa forma, recompor os espaços destinados ao pedestre. Os órgãos públicos responsáveis pelo planejamento e gerenciamento de tráfego, como também pelo planejamento urbano, juntamente com a comunidade e pesquisadores de diversas áreas de conhecimento, devem criar um fórum de debate onde possam estabelecer novas formas de intervenções no espaço urbano, de modo que os aspectos técnicos, sociais, econômicos e culturais se integrem de forma a repensar a cidade a curto, médio e longo prazo. Nota-se, atualmente, em

\section{A gênese da moderna cidade de São Paulo}

Julio Cesar Sazuki

(Orientadora: Sandra Lencioni) diversos municípios, um verdadeiro frenesi relativo às intervenções públicas, na tentativa de recuperar espaços históricos; porém, pode-se indagar se essas propostas de resgate da história, identidade e memória dos patrimônios não é uma necessidade de reafirmar o próprio sistema. A simples recuperação estética não leva a um resultado satisfatório; falta recuperar os símbolos historicamente importantes e significativos e devolver de fato o espaço público ao cidadão. A criação de vias exclusivas para pedestres, alargamento de calçadas, alterações físicas para circulação de portadores de deficiência física, ciclovias, canaletas exclusivas para ônibus, implementação de espaços adequados para o comércio informal, áreas de convivência e lazer, restaurantes populares e outras soluções podem ser implementadas, num processo de revitalização das áreas centrais, com o objetivo de tornar esse espaço um ambiente agradável a todos, devolvendo-o à população, considerando-se como vital a participação efetiva dos diversos agentes envolvidos. Diante disso, o espaço público da rua deve ser rediscutido de maneira a abarcar sua realidade histórico-social e cultural, sua construção subjetiva, uma espacialidade onde as pessoas se identificam por símbolos comuns, representações e mediações, para que se possa efetivamente torná-lo um espaço de sociabilidade, um espaço humanizado.

A produção da aglomeração de São Paulo, entre o início do século XVI e finais do século XIX, foi marcada por amplas modificações em relação ao sistema de arruamento, à definição e uso dos terre- 
nos, à forma de expansão do aglomerado.

Estas modificações estão relacionadas à resignificação da terra na reprodução das relações sociais, ou seja, no bojo da transição do predomínio da escravidão, primeiro, e mercantilização de imóveis em seguida.

A passagem do predomínio da escravidão como fundamento da reprodução das relações sociais para o da mercantilização de imóveis, na produção da aglomeração de São Paulo, está presente

\section{O Sudeste Goiano: as
transformações territoriais da desconcentração industrial brasileira}

\author{
João Batista de Deus \\ (Orientador: Francisco C. Scarlato)
}

Este trabalho analisa as cidades pólos e sua microrregião de influência no sul de Goiás, tendo como estudo de caso a microrregião Catalão. A interpretação geográfica deste trabalho tem como finalidade principal observar como a descentralização econômica e industrial

\section{Eco(turismo) em áreas protegidas: um olhar sobre Fernando de Noronha}

Maria Lucia Costa Lima (Orientadora: Adyr Balestreri Rodrigues)

Este estudo se insere no debate sobre a tendência de crescimento do ecoturismo no mundo e seus impactos na transição de uma sociedade que incorpora, de plus en plus, o movimento das relações de produção capitalistas, substituindo o trabalho escravo pelo trabalho livre, valorizando a terra como negócio extremamente rendoso e constituindo o capital que se torna cada vez mais industrial e urbano.

Trata-se dos novos fundamentos da reprodução das relações sociais determinantes na produção da moderna cidade de São Paulo.

brasileira possibilitou a concentração populacional em poucos e esparsos núcleos espalhados pelo território goiano.

Esses núcleos transformaram-se em pólos econômicos regionais, passando a exercer influência em uma região, exercendo funções de cidade média em áreas de baixa densidade populacional, não atingindo, consequentemente, os indices quantitativos para serem considerados cidades médias pelos órgãos oficiais. Por conta disto, parcela considerável das cidades brasileiras não são consideradas cidades médias apesar de exercerem de fato este papel.

sobre a visitação e o manejo de unidades de conservação, bem como sobre as localidades nas quais se desenvolve. Caracterizado como um estudo de caso e baseado em procedimentos metodológicos notadamente qualitativos, apresenta um cenário do ecoturismo em escala mundial e um panorama da atividade turística no Arquipélago de Fernando de Noronha, situado no Oceano Atlântico, na região 
Nordeste do Brasil. Enfatizando sua relação com o Parque Nacional Marinho, discute os impactos socioambientais e o papel do turismo na promoção da conservação ambiental, na difusão da educação conservacionista e no retorno socio econômico para a população e para o desenvolvimento local. Por meio desta análise, procura demonstrar que o Parque Nacional é um instrumento extremamente significativo para a conservação, para o turismo e, conseqüentemente, para a economia local. A área possui rara beleza

\section{O geoprocessamento no planejamento ambiental: Parque Estadual de Campos do Jordão}

\author{
Everton Valiati Hemerly \\ (Orientadora: Ańa Fani A. Carlos)
}

Este trabalho teve como objetivo integrar técnicas de geoprocessamento na geração de cartas temáticas que servissem de subsidios a análise, ao planejamento e ao monitoramento ambiental em Unidades de Conservação. Para isso, escolheu-se o Parque Estadual de Campos do Jordão - PECJ, no Estado de São Paulo, Brasil, como área de estudo.

Além do turismo intenso no parque, as características climáticas e físicas diferenciadas das demais regiões do Estado de São Paulo, a não atualização do Plano de Manejo desde 1974 e os poucos estudos científicos envolvendo toda a sua área, serviram de estímulo para a realização deste trabalho. Por meio de cartas temáticas, tratou-se de espacializar e representar informações geográficas relacionadas aos seguintes temas: hidrografia, cênica e patrimônio natural e históricocultural únicos. Com estes atributos, a atividade (eco)turística desenvolvida no Arquipélago, pode ser considerada um modelo nacional, desde que continue incorporando princípios indispensáveis para tal, como a ênfase na conservação da natureza, a promoção da educação ambiental, a geração de benefícios para a comunidade local e a satisfação do visitante, tendo por base uma eficiente e estruturada política.

relevo, insolação, uso e cobertura do solo, fragilidade potencial do terreno, áreas de preservação permanente e zoneamento ambiental.

Para produção das cartas temáticas empregou-se as tecnologias de Geoprocessamento: GIS - Sistema de Informação Geográfica, GPS - Sistema de Posicionamento Global e Sensoriamento Remoto. Foram produzidos um mosaico de fotografias aéreas na escala de 1: 12.800, com uma proposta de microzoneamento para a área de Uso Público do PECJ e 10 cartas temáticas, na escala de 1: 50.000, para análises em toda a sua extensão. O uso das técnicas de geoprocessamento permitiu gerar produtos com uma precisão compativel com as escalas de trabalho e dentro dos padrões cartográficos estabelecidos pelo Instituto Brasileiro de Geografia e Estatística - IBGE.

Assim, com base nas análises realizadas sobre o mosaico e as 10 cartas temáticas, principalmente a carta sintese com a proposta de zoneamento ambiental para o PECJ, foi possivel levantar problemas e apontar sugestões para a 
atualização de seu Plano de Manejo e para futuros trabalhos que visem avaliar as influências naturais e antrópicas em Unidades de Conservação, com o intuito de

\section{Fronteira, paisagem e gestão ambiental na microrregião de Brasiléia - Acre, Brasil.}

Adailton de Sousa Galvão

(Orientador: José Bueno Conti)

A ocupação acelerada da Amazônia, sobretudo nas últimas três décadas, provocou profundas modificações na organização do espaço regional e nos padrões de uso da terra, contribuindo para desencadear inúmeros impactos sociais e ambientais, provocados pela expansão da fronteira agropecuária. Os projetos de assentamentos no presente, Santa Quitéria e Quixadá, área objeto do presente estudo, são vistos como um novo modelo de gestão territorial e ambiental. Os dados obtidos demonstram que as transformações espaciais ocorridas na área provocaram intenso processo de degradação das paisagens com efeito,

\section{Percepção da paisagem e planejamento no distrito da Brasilândia-SP}

Marcia Aparecida Silva (Orientador: Felisberto Cavalheiro)

A paisagem é uma categoria de análise que contribui para a compreensão da realidade porque seu conceito supõe a planejamento, recuperação, monitoramento e preservação; além do manejo de suas áreas degradadas.

sobre os aspectos físicos e sociais. Os efeitos adversos podem ser observados na rede de drenagem, na destruição da floresta, na degradação dos solos, nas alterações microclimáticas além, da total ausência de infra-estrutura básica. Nesse sentido, torna-se relevante repensar as práticas utilizadas até o presente momento e desenvolver novas formas de ocupar e produzir o espaço, visando alcançar um desenvolvimento regional sustentável dos recursos. O uso agrícola da terra em pequenas unidades de produção, consorciado com algumas atividades extrativas vem contribuindo como um modelo de aproveitamento das potencialidades regionais. Isso poderá minimizar, os efeitos negativos provocados pelo uso insustentável dos recursos contribuindo, dessa maneira, para a melhoria dos padrões de vida das populações que habitam os referidos projetos.

integração dos elementos do meio biofísico e ação humana, incluindo o seu aspecto peceptivo. Assim, o binômio paisagem e percepção é referência importante para o planejamento urbano. No distrito da Brasilândia, zona norte do município de São Paulo, a ocupação e o uso do solo foram feitos sem critérios, negligenciando as restrições impostas pelo meio biofísico. Essa forma de ocupação reflete em 
grandes problemas sócio-ambientais: moradias precárias, córregos poluídos, enchentes, deslizamentos, escassez de áreas livres e áreas verdes. A percepção da população sobre o lugar é influenciada pelo aspecto cultural e pelo tempo de residência no bairro. As situações do

\section{- As paisagens crepusculares da ficção-científica: a elegia das utopias urbanas do modernismo}

\author{
Jorge Luiz Barbosa \\ (Orientadora: Ana Fani A. Carlos)
}

Nosso tema é a metrópole, lócus da produção material e sígnica de nossa Época. Experiência e concretude da realização de um modelo arquetípico de civilização e progresso que se universaliza: a sociedade urbana. Espaço-temporalidade de fixos e fluxos que imprime e exprime encontros marcados e aleatórios, identidades e diferenças, integração e interdição, desterros e virtudes. Movimentos que se entrecruzam num processo de fusão e fissão, fazendo da Metrópole um quase- mundo e, ao mesmo tempo, um enigma.

Para responder os desafios do enigma da sociedade urbana recorremos a uma dimensão particular do espaço geográfico: a paisagem. Trata-se, portanto, de tomar a paisagem como recurso e abrigo de leitura e interpretação do curso de afirmação da metrópole como experiência de espaço-tempo de homens e mulheres concretos.

A busca da paisagem como possibilidade de desvendamento da metrópole nos conduziu ao diálogo com arte cinema- cotidiano contribuem para a valorização da paisagem. Valoriza-se a casa (aquisição do espaço privado) e as relações de vizinhanças (espaço semi-púbico). Por outro lado, destaca-se a violência como principal fator da baixa qualidade de vida.

tográfica, em especial com gênero de ficção científica. Através das narrativas de ficção-científica desenharam-se paisagens que confessavam nas suas representações de tensões, conflitos e contradições socioculturais , uma rememoração de utopias que emergem da historicidade do fenômeno urbano.

A elaboração do nosso trabalho envolveu uma leitura "lado a lado" entre filmes representativos de cada periodo de ruptura do/no sentido do urbano Metrópolis, Alphaville, Blade Runner e Matrix - , com as propostas de cidades ideais de ícones do movimento modernista. Esse exercício nos conduziu à reflexão crítica do nosso modo de estar e ser urbano, tendo na relação paisagemimagem seu fundamento principal de investigação.

A paisagem revelada e desvelada anunciou caminhos distintos no processo de urbanização: a Obra (o Uso) e o produto (valor de troca). O sentido do espaço urbano é, portanto, uma tessitura complexa e contraditória que faz emergir diferentes sujeitos sociais na sua construção. Construímos metrópoles e somos construidos por elas!

Enfim, nosso trabalho abriga a ambição de compreender a paisagem urbana como produto de concepções éticas e estéticas que atravessam as 
práticas dos sujeitos em situação, anunciando a metrópole como um espaço social habitado por utopias do Ser através da existência.

\section{As agroindústrias da carne do Sul do Brasil}

Carlos Espindona

(Orientador: Armem Mamigonian)

A partir de um quadro geral da agroindústria de carne do Sul do Brasil, procurou-se analisar e compreender os principais processos de reestruturação agroindustrial. Desta forma, a pesquisa trata das estratégias empresariais ado- tadas nos anos 90, tendo como fio condutor a idéia de que as estratégias são condicionadas por suas trajetórias histórica e geográfica. O pressuposto básico é que, em um ambiente de acirrada concorrência inter-firmas, a diferença entre elas, quanto à capacitação tecnológica, escala de produção, diferenciação de produtos, marketing, constituem-se como fator determinante das estruturas geoeconômicas.

\section{Unidades do relevo como proposta de classificação das paisagens da Bacia do rio Curu - Estado do Ceará}

Fátima Maria Soares

(Orientador: Adilson de Abreu)

A presente pesquisa objetiva aplicar os métodos de pesquisa e análise utilizados no estudo integrado da paisagem, campo do conhecimento geográfico, como área de atuação capaz de romper com a dicotomia Geografia da Natureza e Geografia da Sociedade.

Através do estudo integrado da paisagem, foi possivel ter acesso a diversas áreas do conhecimento científico e com a ajuda de técnicas e tecnologias, redimensionar esses conhecimentos fracionados, que são uno e indissociáveis em suas ações e reações.

Para aplicação do estudo, selecionouse a Bacia Hidrográfica do Rio Curu,
Estado do Ceára, na Região Nordeste Brasileira; o critério da escolha, constituise num dos primeiros pontos a ser respeitado pelo método, que consiste a delimitação da área geográfica. As fronteiras naturais vão possibilitar o entendimento no tempo e espaço, de como as transformações de longo e curto período de tempo foram se processando e quais as variáveis que desencadearam tais mudanças.

A área selecionada terá portanto, uma dimensão escalar, que será ponto de referência. As áreas vão sendo redelimitadas em unidades menores, conforme suas características topográficas, e a cada uma delas vão sendo interconectadas informações referentes a sua geologia, que vai-se constituir como suporte delineador das formas, os agentes atmosféricos, como impulsionadores das transformações, o solo e a vegetação, como catalizadores do ambiente natural, e as 
ações da sociedade, como agentes interruptas de mudanças.

A partir da delimitação da área em unidades menores, foram incorporadas em cada uma delas, novas informações, que foram qualificadas, quantificadas e analisadas. Posteriormente, foram atribuidas as variáveis, valores, conforme grau de utilização e de danos ambientais identificados. Toda essa gama de informações

\section{O sistema aquífero Guarani (SAG) no Mercosul}

Pedro C. G. Vianna

(Orientador: José de Queiroz Neto)

O primeiro objetivo deste estudo é compreender o Sistema Aqüífero Guarani, em seu atual estágio de conhecimento. Procura-se entender o funcionamento deste aqüifero, suas áreas de recarga, descarga e suas outras particularidades. 0 conhecimento, ainda que incipiente, do grau de interconexão do Aqüifero Guarani

\section{Histórico e Avaliação do papel da Comissão Interestadual da Bacia Paraná-Uruguai no desenvolvimento regional (1951-1972) São Paulo e Mato Grosso}

Cleonice Gardini

(Orientadora: Ana Maria Marangoni)

O presente trabalho objetiva avaliar - papel exercido pela Comissão Interestadual da Bacia Paraná-Uruguai/ IBPU no desenvolvimento regional da possibilitou testar técnicas de valorização da paisagem, onde entre os critérios estão dados de caráter objetivo e subjetivo, que requer do pesquisador imparcialidade e caráter científicos para que os resultados obtidos, sejam o mais próximo do real.

O documento tornou-se um laudo técnico e científico para serem utilizados como suporte para projetos tanto de cunho sócio-econômico quanto ambiental.

com a superfície e com outros aqüiferos sobrepostos, com os quais forma sistemas mais complexos.

Em segundo lugar procura-se apontar para as questões referentes à gestão das águas do Sistema Aqüifero Guarani no Mercosul, no quadro legal e institucional e, em seu aspecto geopolítico.

Paralelamente se busca saber como será possivel tornar compativel a complexa rede de legislações referente à gestão de águas nos diversos territórios sobrepostos ao aqüífero, com suas unidades físicas.

Bacia Paraná-Uruguai. Criada em 1951, com o propósito de implantar um planejamento regional integrado, a CIBPU constitui-se a partir da reunião dos Estados componentes da Bacia (Mato Grosso, Goiás, Minas Gerais, São Paulo, Paraná, Santa Catarina e Rio Grande do Sul), permanecendo até 1972.

Procurando entender o desempenho da Comissão, procedemos inicialmente ao resgate das principais propostas de ação, destacando-se a navegação, a interligação 
de bacias hidrográficas, a produção de energia elétrica e a industrialização.

A partir da análise de suas particularidades, tais como estrutura interestadual, planejamento integrado e área de abrangência, buscamos verificar os desdobramentos e repercussões mais recentes do planejamento pretendido.

Esta pesquisa dá destaque aos Estados de São Paulo e Mato Grosso, em face do primeiro ter sido o Estado no qual os estudos da CIBPU tiveram maior alcance, e o segundo por ser uma escolha pessoal ligada a nossa profissão.

Para a exploração desse tema utilizamos como fontes os relatórios anuais da CIBPU, os próprios estudos por ela realizados e também entrevistas com pessoas ligadas à Comissão.

\section{- Dinâmica da Água em Campos de Murundus do Planalto dos Parecis}

Prudêncio Rodrigues de Castro Júnior (Orientador: José Roberto Tarifa)

A dinâmica da água em campos de murundus do Planalto dos Parecis é estudada neste trabalho por meio de observações de campo realizados na Fazenda São Fidel, município de Sorriso, estado de Mato Grosso. Esses campos, nitidamente dependentes do regime pluvial, possuem grande importância para a conservação da água de superfície e da biodiversidade, por estarem diretamente ligados aos cursos d'água formadores das bacias hidrográficas, como também por abrigar numerosas espécies florísticas e faunísticas do cerrado brasileiro.

O trabalho tem como objetivo principal conhecer a dinâmica da água e a estrutura pedológica de um campo de murundus, também conhecidos como microrrelevos, e regionalmente, por monchões, cocorutos, covoais, ilhas e capãozinhos, utilizando-se de revisão bibliográfica, interpretação de imagens de satélite e fotografias aéreas, levantamento dos solos com procedimentos da análise estrutural da cobertura pedológica, e estudos climatológicos, por meio da análise de dados pluviométricos a partir de 1985 e de dados piezométricos obtidos durante coleta sistemática em duas vertentes representativas de um campo de murundus do Planalto.

Os principais resultados obtidos, referem-se à origem dos murundus por diferentes teorias, uma geomorfológica e outra biológica, estas paisagens ocorrem ao redor dos cursos d'água formadores da bacia hidrográfica, apresentando configuração e distribuição distinta em cada setor da vertente. Nos campos de murundus estudados o solo que ocorre na base da vertente é o PLINTOSSOLO ARGILÚVICO Distrófico, enquanto que na parte média e superior da vertente ocorre o LATOSSOLO BRUNO Distrófico câmbico e o Distroférrico plíntico, sendo que a característica comum e notável destes solos é a presença de concreções ferruginosas formando o horizonte plíntico, correspondendo ao nível de oscilação do lençol freático.

A dinâmica da água nos campos de murundus possui comportamento peculiar, diretamente ligado ao regime pluviométrico, mantendo-se saturados ou supersa- 
turados em água nos meses chuvosos, esvaziando-se lenta e continuamente nos meses secos, por meio do rebaixamento do nível freático a uma taxa média de $17 \%$ ao mês. O estudo realizado indica a presença de dois lençóis, um suspenso de características sazonais e outro perene e profundo, separado do anterior por uma camada argilosa confinante.

Os dados obtidos foram utilizados no sentido de compreender a dinâmica hídrica

\section{- Clima e produtividade da soja nas terras do cerrado sudeste de Mato Grosso}

\section{Jeater Waldemar Mariel Correa Santos}

(Orientador: José Roberto Tarifa)

O principal propósito deste trabalho é analisar a influência do clima na produção da soja no sudeste do estado de Mato Grosso. Considerando que o sistema de produção desta cultura é baseado em exploração em larga escala bem como no uso maciço de tecnologias modernas como produtos bioquímicas, fertilizantes, e sementes geneticamente melhoradas (variedades precoces, médias e tardias) e estratégias de plantio que combinam diferentes datas e ciclos dos cultivares (calendário agrícola), a questão principal que se coloca é: Será que o ritmo climático controla, ou não, a produção deste tipo de agricultura?

Para desenvolver este trabalho, foram escolhidas algumas "áreas-teste" no estado do Mato Grosso(Br), que retratassem a produção de sementes e grãos de soja. Deste modo, em função da disponibilidade e da contabilidade dos nos campos de murundus, bem como a estrutura pedológica, o regime pluviométrico, o comportamento piezométrico, as relações com a rede hidrográfica, a sua função no bioma do cerrado, e ainda avaliar o impacto ambiental, devido ao rebaixamento do nível freático por meio da escavação de uma rede de drenos, possibilitando assim a prática da agricultura mecanizada nessas áreas naturalmente impróprias.

dados (informações meteorológicas, pedológicas e fenológicas dos cultivos), foram selecionadas as fazendas Farroupilha, Girassol, São Jerônimo e Verde produtoras de sementes - e as fazendas Juriti, Los Angeles, SM I, SM3 e SM5 produtoras de grãos.

Para estimar um balanço hídrico seqüencial (FRERE \& POPOV, 1986), calculado para atender especificamente as necessidades fenológicas do cultivo da soja, foram utilizados dados diários de pluviosidade, referentes ao período compreendido entre os anos de 1991 e 2000. Por outro lado, foram feitas tentativas de correlação e análise de regressão entre a produção anual de cada lugar (fazenda ou talhão) e os resultados do balanço hídrico. Com o fim auxiliar na compreensão das análises, foram realizadas entrevistas com diversos produtores e técnicos das empresas de assistência técnica, bem como trabalhos de campo que acompanhassem a realização das operações agrícolas.

Em conclusão, os resultados demonstraram que:

a) o ritmo climático nas áreas de produção de soja (principalmente nos topos eleva- 
dos da Serra da Petrovina) é muito regular,

b) somente quando se têm desvios muito acentuados em relação ao "ritmo habitual" é possivel observar e, eventualmente,

\section{Tendências e variabilidade do fenômeno pluvial na região metropolitana de São Paulo e possíveis vinculações com o processo de urbanização}

\author{
Edson Cabral \\ (Orientador: José Bueno Conti)
}

Esta pesquisa teve como objetivo principal verificar os possiveis impactos do forte processo de urbanização da Região Metropolitana de São Paulo no seu comportamento pluviométrico. As hipóteses levantadas são de que tal processo afetou o comportamento pluviométrico na área de estudo, gerando o aumento de episódios de chuvas torrenciais e a diminuição de precipitações mais leves (inclusive a garoa). Aspectos de localização do sitio e sua conformação topográfica, além de causas de origem regional e global, tem papel importante na distribuição temporo-espacial das chuvas. A metodologia empregada neste trabalho é a da Análise de Séries Temporais, para verificar a existência de tendências nas séries pluviométricas selecionadas, com registros de periodos a partir de 30 anos. Inicialmente, foram analisadas as séries de totais anuais e sazonais (verão, outono, inverno e primavera) de precipitação de 37 postos pluviométricos, escolhidos de isolar as influências meteorológlcas, tal como aconteceu no ano de 1994/95,

c) o tipo de sistema agrobiotecnologico empregado no sudeste do estado de Mato Grosso minimiza os efeitos climáticos no rendimento final da cultura da soja.

um total de 139 , obtendo-se, em relação aos valores anuais, 14 séries com temdências positivas e as demais 23 séries com tendência nula, porém, em sua maioria, com incrementos pluviométricos. Outra análise foi feita em relação às séries de freqüências de dias de precipitação, também com valores anuais e trimestrais, encontrando-se, em relação às 32 séries escolhidas em termos anuais, 21 delas com tendência positiva, 9 com tendência nula e somente $2 \mathrm{com}$ tendência negativa. As séries de freqüências de dias de precipitação mais intensa (a partir de 30 $\mathrm{mm} / \mathrm{dia}$ ) e mais tênues (abaixo de 3 $\mathrm{mm} / \mathrm{dia}$ ) foram também estudadas em termos anuais e trimestrais para 5 séries selecionadas, sendo duas delas localizadas em área urbana, duas situadas na periferia da mancha urbana e uma inserida na área rural da Região Metropolitana. Com relação às chuvas de maiores intensidades, apesar da heterogeneidade dos períodos analisados e da variabilidade temporal dos valores, as séries localizadas em áreas mais urbanizadas mostraram valores mais expressivos de aumento de dias de precipitação mais fortes. As chuvas de menores intensidades mostraram valores decrescentes nas duas estações urbanas e valores crescentes nas demais. Foi estudada também a questão de um possivel ciclo semanal da precipi- 
tação, com a análise de 67 anos de registros diários de precipitação da Estação Meteorológica da Àgua Funda. Os resultados não apontaram uma relação estatisticamente significativa dos dias da semana com a ocorrência de chuva na área urbana de São Paulo. Outro aspecto analisado foi o das chuvas e suas repercussões na saúde pública, analisando-se a vinculação da precipitação pluviométrica e dos casos de leptospirose, mostrando uma alta correlação entre esses dois parâme-

\section{As teconologias multimeidias- telemáticas na prática de ensino do meio ambiente: uma abordagem interdisciplinar}

\author{
Rosangela Maria Cunha
}

(Orientadora: Magda A. Lombardo)

Esta pesquisa teve como objetivo investigar concretamente as possiveis contribuições do uso da multimídiatelemática no trato das questões ambientais referentes ao Ensino Médio em Escolas Públicas Paulistas. Procurou-se verificar se há melhoria de aprendizagem dos conceitos ambientais pelos alunos com a introdução da multimídia-telemática no processo ensino-aprendizagem, com pesquisa de campo realizada no período de 1997 a 2000. A metodologia empregada neste trabalho partiu da pesquisa qualitativa na educação, com enfoque fenomenológico, de estudo de caso com abordagem interdisciplinar Iniciou-se em 1997 com levantamento empírico-diagnóstico da realidade escolar na cidade de São Paulo, com 184 professores, o perfil docente e o uso de recursos audiovisuais de suas tros. De uma forma geral, os resultados desta pesquisa apontam no sentido de existirem indicios de efeitos urbanos sobre a precipitação, particularmente no que se refere ao aumento e recorrência de episódios de chuvas torrenciais, que causam grandes distúrbios areolares na Grande São Paulo e a diminuição da freqüência de dias de precipitação mais leve em estações mais urbanas, aí incluindo a famosa garoa paulistana.

escolas. Em seguida, inicia se o estudo de caso em Rio Claro, em uma primeira fase da pesquisa, com 752 questionários e, nesta cidade, com três escolas, obtém-se o perfil do alunado: o sócio-econômico e o de conhecimentos dos conceitos sobre a temática ambiental e de contato com a informática; e ainda, entrevistas com os professores participantes da pesquisa. Na segunda fase, com 361 questionários, a que os alunos responderam opinando sobre o CD-ROM e sobre questões relativas aos conceitos ambientais, cujas respostas não foram corretas na primeira fase da pesquisa em 1997; assim, estes conceitos são reapresentados no questionário de 2000 e no CD-ROM elaborado especialmente para o ensino médio: MeioAmbiente e Ciências Atmosféricas pelo CPTEC/INPE/UNESP/UFMG, cujas aulas foram elaboradas por especialistas e que teve também como orientação os resultados dessa pesquisa nas escolas participantes. Os professores que participaram direta, e indiretamente da pesquisa responderam também a questionários (20) e a entrevistas. São apresentadas discussões sobre os parâmetros, documentos 
oficiais para o ensino médio que tratam da temática estudada. Mostram-se ainda os conceitos ambientais como são apresentados, em três livros didáticos, um livro paradidático e no CD-ROM. Procura-se fazer uma análise do estudo de caso, das dificuldades encontradas na realidade escolar, da possibilidade de continuidade deste tipo de projeto no sistema escolar Apesar das dificuldades encontradas, os resultados deste estudo apontaram existir relações entre o ensino com o uso da

\section{A dinâmica têmporo-espacial do clima subtropical na região conurbada de Florianopolis-SC}

\author{
Magali Mendonça \\ (Orientadora: Magda A. Lombardo)
}

A presente pesquisa teve por objetivo estudar o clima da região conurbada de Florianópolis, buscando compreender a influência simultânea dos fatores geoecológicos e da urbanização na variação têmporo-espacial da temperatura e outros elementos como a umidade e os ventos.

Foram feitos levantamentos de dados meteorológicos em várias localidades da região, utilizando-se equipamento digital para registro da temperatura e umidade relativa do ar, além de observações sensiveis para outros elementos como direção e intensidade do vento, nebulosidade, visibilidade e tráfego.

Além do mapeamento do uso da terra na região, procurou-se quantificar o tráfego de pessoas e veículos/min. e caracterizar a ocupação dos entornos de cada estação pontual episódica. multimídia-telemática e a melhora de aprendizagem. Contudo, tal melhora só é possivel não só com a construção de novas tecnologias, mas principalmente com a capacitação de professores e alunos, buscando-se a contextualização dos conteúdos tratados, inseridos no currículo escolar, como parte integrante da proposta pedagógica escolar construída pela e para a escola, onde o aluno deve ser a base e o sujeito da construção do conhecimento.

Os levantamentos foram efetuados durante quatro dias, nos horários sinóticos, em cada estação do ano, buscando sondar diferentes tipos de tempo. A análise do tempo e clima foi realizada em diferentes escalas têmporoespaciais.

Para avaliação da conservação de calor, os dados registrados foram comparados à estação do aeroporto, escolhida como representativa das áreas rurais ou suburbanas. Para a análise dos resultados, mapas, transetos e transeções foram elaborados com a distribuição da temperatura, umidade relativa do ar e direção do vento. As ilhas de calor e frescor foram evidenciadas através de mapas do gradiente de temperatura.

O exame comparativo do material cartográfico demonstrou significativa conservação de calor nos locais com ocupação mais verticalizada, adensada e de maior tráfego. Não se observou a formação de uma ilha de calor contínua, mas de um "arquipélago", o que reflete bem o caráter multinucleado da urbanização, derivado, em parte, da compartimentação morfológica do sítio urbano. 
As maiores diferenças de temperatura, caracterizando ilhas de calor mais intensas, ocorreram no setor central da região, sob domínio polar às $6 \mathrm{~h}$, enquanto em situações de transição e prenúncio frontal as maiores diferenças foram registradas às $15 \mathrm{~h}$. Nestas situações as elevadas temperaturas combinam-se a também elevada umidade relativa do ar

\section{Tl Comércio de Múltiplas Filiais no Sul do Brasil}

\section{José Messias Bastos \\ (Orientador Armem Mamigonian)}

O desenvolvimento autônomo do comércio no Sul do Brasil deve-se ao tipo de estrutura sócio econômica constituído pelas colônias de povoamento estabelecidas ao longo de vários séculos de sua ocupação. As constantes e acirradas disputas pelo mercado consumidor local e regional desembocou a partir dos anos 50 em processos de modernização e de sólida expansão. Resultando no quase fechamento da região aos capitais locais.

No estudo histórico geográfico do comércio no Sul do Brasil a partir do

\section{Pedrinas Paulista: memória e invenção}

Giliola Maggio de Castro

(Orientadora: Liliana Laganá)

Este trabalho analisa como se manifesta e se desenvolve a construção de um espaço imaginário - a invenção de uma Pátria - em Pedrinhas Paulista, comunidade italiana fundada no Pós- resultando no aumento da sensação de calor

Esses condicionantes climáticos mostram-se importantes na avaliação da qualidade ambiental, de modo que estudos detalhados dos elementos do tempo e clima devem compor os diagnósticos para o planejamento urbano, visando o conforto térmico e a qualidade de vida.

paradigma de formação sócio-espacial verificou-se que a agressividade dos capitais regionais vincula-se diretamente as bases materiais as quais, esses capitais, estão apoiados. Por isso não só acompanharam as principais transformações que ocorreram nas últimas décadas no Brasil como também em muitos caso partiram na frente (auto-serviço, leitura óptica, etc.).

Contudo as imposições conjunturais direcionadas ao Brasil pelo imperialismo americano (sobrevalorização do Real, juros altos e abertura comercial) promovem a entrada das grandes redes do varejo mundial e nacional (Sonae, J.C. Penney, Carrefour, Pão-de-açúcar, Ponto Frio) principalmente na forma de aquisição de consolidadas redes regionais.

Guerra e localizada na Alta Sorocabana no interior do Estado de São Paulo.

Além da Bibliografia já existente, utilizaram-se entrevistas gravadas, questionários, redações e depoimentos dos habitantes do lugar, abrangendo as várias faixas de idade, tentando verificar até que ponto a memória dos mais velhos se mantém e se perpetua nas novas gerações através da língua, dos costumes e da percepção do espaço construído. 


\section{Dissertações de Mestrado}

\section{O turismo na região de Visconde de Mauá- impactos sobre o meio ambiente}

\author{
Andrea Ap. Mussato
}

(Orientador: Mário de Biasi)

Este trabalho, a partir da investigação empírica, mostra os impactos do turismo, principalmente os negativos, sobre os principais vilarejos que compõem a Região de Visconde de Mauá. Região localizada a Sudoeste dos Estados do Rio de Janeiro e Minas Gerais e a Leste do Estado de São Paulo. Esses impactos são observados por interméuiio dos olhares dos atores que fazem parte do cenário turístico da região: a população residente, os comerciantes e os turistas e pela análise crítica do olhar do turista-geógrafo, que somos, embasados pelo conhecimento teórico e a intensa vivência com o lugar

Por meio do trabalho de campo, entrevistas in loco, questionários aplica- dos, imagens fotográficas da região e o aporte da pesquisa bibliográfica, caracterizamos a Região de Visconde Mauá, como um pólo receptor de turistas, dotada de vários atrativos naturais, o que atrai além de turistas, um considerável número de pessoas vindas de outras localidades à procura de novas oportunidades de emprego. A região não possui nenhum tipo de gestão e planejamento que ampare ou freie a degradação causada sobre o meio ambiente, desde quando era um Núcleo Colonial e agravado pelos impactos causados pelo turismo freqüente de agora.

A partir dos resultados obtidos, registramos algumas propostas e soluções para que os órgãos competentes e a sociedade responsável pela localidade se organizem e concretizem ações de conservação e equilíbrio do processo impactante no meio ambiente de Região de Visconde Mauá.

\section{A Modernidade no Rio de Janeiro: A construção de um cenário para o turismo}

Marcello de Barros Tomé Machado

(Orientadora: Adyr A.B. Rodrigues)

O advento da modernidade propiciou o surgimento de um importante fenômeno sócio-espacial: o turismo, que já na segunda metade do século XIX, apresentava importantes fluxos, principalmente na América do Norte e na Europa, tendo como principal icone a Cidade de Paris, cuja reforma urbana liderada por
Haussmann tornou-a o grande exemplo de cidade moderna e atrativa turisticamente para a população mundial.

Naquele mesmo período, o Rio de Janeiro era uma cidade feia e insalubre, com ruas estreitas, sombrias e úmidas, edificações mal feitas e assolada por constantes pestilências, longe, portanto, de ser considerada uma cidade moderna e atrativa turisticamente.

A presente dissertação pretende destacar as transformações que modernizaram o Rio de Janeiro, possibilitando a formação do cenário para o surgimento do turismo moderno, tornando a cidade um 
importante centro turístico da modernidade, cuja beleza a fez merecer o título de Cidade Maravilhosa.

\section{Ti A Proposta e a Prática da Questão Ambiental: Uma análise da coerência em ralação ao turismo em Bertioga}

Maria Eliza de Sales Amaral Siqueira

(Orientador: Eduardo A. Yázigi)

Estudo da coerência entre as propostas e práticas envolvendo o turismo e a questão ambiental no litoral do Estado de São Paulo, enfocando principalmente a última década. Bertioga é o estudo de

\section{Espacialidade e territoria-} Tidade dos grupos ciganos na cidade de São Paulo

\author{
Virginia Rita dos Santos \\ (Orientador: André Roberto Martin)
}

Esta dissertação de Mestrado analisa a questão da Espacialidade e da Territorialidade dos Grupos Ciganos na Cidade de São Paulo, discutindo os processos de apropriação do espaço por parte dos grupos nômades e sedentários e a prática do nomadismo como uma das formas de preservação cultural dos grupos ciganos, garantindo-Ihes sua autonomia econômica e social.

Através de uma sinopse histórica da trajetória cigana no mundo ocidental, caso, município localizado na Baixada Santista.

Discutimos os conceitos de turismo, relacionado aos de território, "desenvolvimento ambientalmente sustentável", mercadoria e ideologia, bem como analisamos o seu crescimento voltado para a valorização ambiental, para a fundamentação teórica.

A pesquisa revela a existência de contradições entre a proposta e a prática, subsidiando a hipótese da necessidade de inter-relacionamento entre turismo e território.

também aqui é analisadas a questão do sedentarismo cigano e suas conseqüências, para os grupos envolvidos, além de algumas considerações teóricas sobre a questão das minorias étnicas, principalmente no tocante a discriminação e ao preconceito da sociedade majoritária frente ao cigano.

A pesquisa teórica está calcada em concepções da Geografia da Percepção e sobre a construção da específica territorialidade dos grupos sedentários e nômades dentro de um contexto urbano complexo que é a cidade de São Paulo, evidenciando o processo de marginalização que sofre os ciganos, principalmente os nômades dentro desta área especifica da pesquisa. 


\section{Solo pobre, terra rica: paisagens do cerrado e agropecuária modernizada em Jataí, Goias}

Ivanilton José de Oliveira

(Orientadora: Claudette Junqueira)

Jataí, município do sudoeste goiano, é um bom exemplo da dinâmica de ocupação das paisagens na área core do cerrado brasileiro. Seus ambientes rurais, outrora dominados por cerrados, campestres e matas, cederam lugar às paisagens antrópicas, compondo um cenário homogeneizado e simplificado.

Este trabalho procura demonstrar as características dos ambientes naturais de Jataí, como sua geologia, seu relevo, seus solos, seu clima e sua vegetação original, na tentativa de vislumbrar suas interrelações, expressas na forma de unidades de paisagem. Apresenta, também, a dinâmica da ocupação de terras no muni- cípio, enfocando principalmente o período após os anos 50, do século XX.

O conhecimento das paisagens naturais e como elas foram sendo ocupadas pelas atividades produtivas permitiu uma discussão sobre a sustentabilidade das formas de uso da terra em Jataí, em especial com o processo de modernização agropecuária, que marcou a consolidação dos espaços destinados à produção agrícola de caráter estritamente comercial. A análise enfoca tanto os ganhos quanto os problemas oriundos dessa transformação socioespacial.

A execução das etapas da pesquisa esteve pautada pelo uso das chamadas geotecnologias, como os sistemas de informações geográficas (SIG) e os produtos de sensoriamento remoto, cujas aplicações na análise geográfica são inúmeras, mas que ainda são pouco exploradas ou subutilizadas, principalmente nas atividades de gestão do espaço e análise ambiental.

\section{Da terra tradicional e território indígena: o processo de territorialização dos índios tupiniquins de Aracruz}

João Marçal Bode de Moraes

(Orientador: Ariovaldo U. Oliveira)

Esta dissertação examina as transformações territoriais sofridas por uma sociedade indigena - a Tupiniquim -, percorrendo os meandros históricos que concorreram para uma contínua redução territorial até culminar em um verdadeiro confinamento quando da chegada de um projeto econômico de grande vulto - a empresa Aracruz Celulose - no município de Aracruz. Igualmente examina as conseqüências do ingresso de elementos exógenos ao local, que ocasionaram uma reorganização social, política e econômica na tradicional sociedade Tupiniquim, obrigando-a a grandes mudanças em seu modo de vida e relações.

Este trabalho de pesquisa mostra, assim, como o grupo foi profundamente marcado pela situação fundiária estabelecida pela instalação da empresa e posteriormente pela redução das áreas quando da demarcação das terras. Esta redução contribuiu em muito para que se estabelecessem novas relações econô- 
micas e sociais com a outra população, originando uma situação de desigualdade em que os índios, assim reconhecidos pela

\section{Espaço nacional e integração competitiva: impasses da política territorial no Brasil}

Clerisnaldo Rodrigues de Carvalho

(Orientador: André R. Martin)

Este trabalho é uma tentativa de se compreender os resultados espaciais do processo de "inserção competitiva" do Brasil e suas relações com o Mercosul. Para tanto, busca-se um escopo teórico explicativo que nos remete à América Latina dos anos 90, e suas políticas sociedade local, encontram-se em desvantagem. econômicas de abertura e privatizações denominada de "ajuste estrutural" Estas por sua vez, foram vistas como únicas respostas possiveis à "globalização" Todo este quadro compõe o cenário dominado pela ideologia hegemônica: o "neoliberalismo" Desnudar os componentes ideológicos desse discurso, cotejando-o com a realidade dos resultados obtidos objetivamente em uma década de experimentação do projeto neoliberal no Brasil, constitui o objetivo final desta pesquisa.

\section{Da fartura à escassez: a agroindústria de celulose e o fim dos territórios comunais no Extremo Norte do Espírito Santo}

Simone Raquel Batista Ferreira (Orientador: Ariovaldo U. Oliveira)

Até meados de século $X X$, a região fronteiriça entre o Espírito Santo e a Bahia era predominantemente ocupada por comunidades extrativistas, camponesas, caboclas, pescadoras e quilombolas que produziam sua existência predominantemente através do uso extrativista e comunal do meio natural. Aqui, a rica floresta tropical atlântica, agrupando mata densa nos terrenos sedimentares terciários e áreas alagadiças nas planícies de inundação dos rios, apresentava a fartura suficiente para suprir estas comunidades de água, peixe, carne, frutos, madeira, ervas e raízes medicinais. A fartura estendia-se à terra: no "sertão" de Itaúnas, a "terra era a rola" e apropriada pelas posses que passavam de pai para filho. Esta situação favorecia o uso comunal dos recursos oferecidos pela floresta e assim concretizava o território das comunidades.

A partir da década de 1950, as áreas de floresta passam a adquirir valor comercial. O crescimento urbano-industrial do centro-sul do país tem fome de madeira, que começa a ser saciada pela exuberante Mata Atlântica do norte capixaba. Em meados da década de 1970, as terras que ainda apresentavam exemplares da floresta concentravam-se no município litorâneo de conceição da Barra e, a partir de então, passam a ser inseridas no projeto estatal de plantio de 
eucalipto para produção de celulose do II Plano Nacional de Desenvolvimento (1974).

A implantação da monocultura da Aracruz Celulose nesta região a partir de 1974 traz a transformação no uso da terra, incentivada e legitimada pelo Estado através de legislações específicas, e impõe uma nova lógica de apropriação de espaço, ditada pela propriedade privada, pelo uso restrito, pela acumulação e pelo lucro. Junto dela, o comportamento ambiental da monocultura e seu manejo extremamente impactantes, com o plantio em nascentes e zonas de recarga hídrica, a retirada de matas ciliares, a exploração de areia e argila encontradas no fundo de antigas lagoas e agora utilizadas na manutenção das estradas, a capina e o controle químico de pragas com elevadas doses de agrotóxicos e herbicidas. Danificando o meio natural, a nova situação

\section{- Fogão de Lenha - Chapéu de palha. Jauenses Herdeiros da rusticidade no processo da modernização}

\section{Neusa de Fátima Mariano}

(Orientador: Heinz Dieter Heideman)

O caipira, entendido como um ser cultural singular, cujo modo de vida é caracterizado pela rusticidade dos meios de reprodução, não passa intacto à entrada do capitalismo no campo. Ele se transforma perdendo e modificando alguns de seus elementos culturais, pois a vida passa a se dar numa sociedade mediada pelo dinheiro. passa a desestruturar o modo de vida das comunidades locais, outrora estruturado numa forma de manejo que mantinha os ciclos reprodutivos da vida.

Estabelecendo a integração entre a produção do conhecimento e a dinâmica social, a investigação destas histórias de vida tomou corpo coletivo no Movimento Alerta contra o Deserto Verde, formado por entidades e ONG's do Espírito Santo e sul da Bahia em meados de 1999 objetivando o questionamento político do projeto celulósico aí implantado. O Deserto Verde vem estimulando a discussão sobre os problemas trazidos pela agroindústria de celulose as comunidades locais e tem contribuído com algumas conquistas, como a lei estadual que determina o zoneamento agroecológico do Espírito Santo e outras recentes leis municipais que próbem o plantio do eucalipto para a produção de celulose.

A pesquisa tem como preocupação central o entendimento de como se deu este fenômeno em Jaú, município do interior do Estado de São Paulo. Vamos encontrar nas colônias de suas fazendas e nos seus sítios, uma sociabilidade muito forte que favorecia a manutenção de expressões de uma cultura singular, enriquecida pelos imigrantes europeus que vieram ao Brasil para trabalhar nos cafezais, no início do século XX.

Com o sistema de salários adotado por lei no campo, na década de 1960, houve a individualização do trabalho, deixando de ser familiar na colônia, para ser assalariado, em que as famílias passaram a morar nas cidades. 
Nos anos 50, a produção canavieira que se expandia pelo interior do Estado de São Paulo foi, aos poucos, acabando com as pequenas propriedades, pois os sitiantes que se viam sem financiamentos bancários (pois os juros eram altos) acabavam vendendo ou arrendando as suas terras. Os fazendeiros, por sua vez, começaram a substituir o café pela canade-açúcar

Tais acontecimentos do setor econômico provocaram uma crise cultural, desvinculando o trabalho da cultura do caipira, desvinculando as suas manifestações culturais do ciclo da natureza,

\section{Município de Barueri: segre- gação espacial e clientelismo político na metrópole}

Adeilson G. Silva

(Orientadora: Amália Inês G. Lemos)

"Nem tudo que reluz é ouro" É com esse ditado que começaremos esse resumo. O município de Barueri possui a $7^{a}$ maior arrecadação de receitas do Estado de São Paulo. Pode-se encontrar todos os equipamentos urbanos necessários à boa qualidade de vida dos munícipes. Porém esse fato não é totalmente percebido quando se percorre o território barueriense. O municipio possui bairros nobres transformando o seu modo de pensar, ser e agir

O que se pretende com esta pesquisa é demonstrar como o capitalismo, transfigurado em uma sociedade moderna mediada pelo mercado, tem o poder de modificar a cultura e o modo de vida do homem rural.

Atualmente, por meio de pesquisa empírica, encontramos heranças da rusticidade, pois nem todos os jauenses mantêm na mesma intensidade e maneira, traços de um modo de vida caipira, presente somente no passado; são herdeiros de si próprios, migrantes da temporalidade.

(condominios fechados) que apresentam toda infra-estrutura necessária à sua população, enquanto os espaços periféricos pobres não providos dos mesmos equipamentos. É visivel a segregação social e espacial. Isso está relacionado a diversos fatores que estudaremos a seguir Outro fato que merece destaque está diretamente vinculado aos homens públicos. Esses se utilizam de um clientelismo político, baseado na doação de diversos serviços assistenciais, para se manter no poder. O espaço local reflete a somatória dessa contradição que se estabelece entre o poder econômico dos mais fortes e a grave situação das camadas desprivilegiadas.

\section{Brasil, Política Cultural e Identidades no Mercosul}

José Eduardo de O. Santos

(Orientador: André R. Martin)
O conceito de identidade constitui uma representação auto-conferida e incorporada por grupos sociais como mecanismo de afirmação e diferenciação de suas formas específicas de cultura. As 
atuais re-configurações espaciais propiciadas pela nova organização econômica do capitalismo mundial, com a conformação de blocos regionais que reúnem povos de distintas culturas, tem provocado cisões e redefinições identitárias importantes, e também vem provocando a emergência de identidades que se supunham esquecidas. Essa situação, ao mesmo tempo que impulsiona a organização de blocos, vem complexificando os processos de integração regional, e parecem impor a necessidade de rearticulação e acomodação de sistemas de identificação cultural vis a vis as mudanças políticas, econômicas, culturais e espaciais. Neste trabalho, procuramos atualizar a discussão teórica acerca dos conceitos de identidade e cultura na América Latina e verificar sua presença, usos e estatuto nos discursos sobre a integração no Cone Sul, a partir

\section{O setor de equipamentos pesados no Brasil: ABB, GE e W.}

\author{
Luciana Antonini \\ (Orientador: Armem Mamigonian)
}

O objetivo principal deste estudo é a compreensão das transformações das grandes indústrias decorrentes da chamada "globalização" dos mercados. Pretende situar a importância da indústria de equipamentos elétricos pesados e visualizar o desempenho deste setor no desenvolvimento da economia brasileira. A Asea Brown Boveri - ABB foi selecionada como indústria principal para ilustrar $\mathrm{e}$ aprofundar o conhecimento destes processos por ser uma das empresas líderes do segmento de geração e trans- do Mercado Comum dos Sul - Mercosul. Para tanto, estabelecemos as relações entre os processos de formação de identidade e as noções de pertencimento cultural, dedicando particular atenção aos conceitos de lugar e região. Como hipótese geral de pesquisa, perguntamos se os processos de integração econômica podem prescindir, para o atingimento dos objetivos econômicos a que se propõem, de mecanismos de efetiva integração cultural dos países-membros e da harmonização das representações identitárias de seus povos, e, consequentemente, se necessitam criar representações identitárias de caráter regional. Como resposta provisória à questão, advogamos a necessidade de considerar, num plano de grande importância, os conteúdos simbólicos das culturas nas estratégias de integração.

missão de energia elétrica no Brasil, e é a maior empresa mundial do setor de energia.

Frente a estes objetivos, foi justificada a importância da indústria de equipamento elétrico pesado para o desenvolvimento econômico e industrial e a contextualização do crescimento deste setor no processo histórico brasileiro, desde sua formação, e qual o papel desempenhado pelo Estado. Por fim, foi realizado 0 estudo de caso de uma empresa, a ABB, para melhor entendimento destes processos. Para tanto, esboçou-se um histórico do conglomerado, e a seguir, foi mostrado seu desempenho, tanto no Brasil como mundialmente. E para melhor compreensão destes processos e comparação entre empresas 
congêneres, foram também observadas a General Electric e Weg.

\section{Tensoriamento Remoto Aplicado ao Estudo da Dinâmica Hidro- lógica da Região da Nhecolândia, Pantanal Matogrossense, MS.}

Benjamin Capellari

(Orientador: José Pereira de Queiroz Neto)

O objetivo deste trabalho é discutir aspectos da aplicação do sensoriamento remoto ao estudo da dinâmica hidrológica

\section{Planejamento e Gestão dos Recursos Hídricos na Região Metropolitana de São Paulo: Diagnóstico Crítico}

\author{
Andréa Spörl \\ (Orientador: Jurandyr L. S. Ross)
}

Este trabalho consiste em uma reflexão sobre as políticas aplicadas aos recursos hídricos no Brasil e, especificamente, na Região Metropolitana de São Paulo. Para lograr tal objetivo buscamos enfocar essas políticas do ponto de vista político-econômico, isto é, em qual contexto político e econômico elas se da região da Nhecolândia, no Pantanal mato-grossense, MS. Selecionou-se para estudo imagens de satélite LANDSAT-TM, que apresentam aspectos hidromorfológicos do Pantanal - Baixa Nhecolândia para a elaboração de modelos cartográficos numa área teste - Fazenda Firme - através da abordagem fotointerpretativa digital e analógica de imagens das cheias e secas na região.

deram, de que maneira foram decididas, quais atores foram envolvidos nesse processo, quais os produtos dessas políticas (planos e leis), como o planejamento influenciou os processos decisórios e, evidentemente, quais as conseqüências e reflexos dessas decisões para as políticas públicas em questão e para seus eventuais beneficiários. Por fim, procuramos traçar o perfil institucional e as formas de gestão predominantes no setor, apontando as deficiências para compreender os problemas atuais, assim como a influência das novas conjunturas nacionais e internacionais na mudança do perfil do sistema de gestão das águas.

Representações Cartográficas e Leitura do Espaço

Geográfico: Um ensaio didático de Geografia no ensino médio
Rosemeire Morone

(Orientador- Maria Elena R. Simielli)

Este trabalho procurou fazer uma reflexão sobre a prática pedagógica no ensino escolar de Geografia, focalizando 
as dificuldades enfrentadas pelo professor iniciante na transposição didática do saber universitário para o saber ensinado e na escolha das metodologias a serem utilizadas em sala de aula.

Procuramos uma metodologia que auxiliasse nossos jovens a sistematizar e compreender o grande volume de informações a que temos acesso hoje e correlacioná-las a sua própria realidade. Optamos por testar a proposta de SIMIELLI (1996), para o ensino de Geografia e Cartografia, através de um teste elaborado para ser aplicado em escolas de ensino médio.

Inserimos as representações cartográficas em sala de aula, com o propósito de capacitar os educandos a: compreender a utilização de dados estatísticos na elaboração de mapas e, a partir dessa

\section{Caracterização dos invernos no sul do Brasil em função dos dias de neve e de precipitação das massas de ar}

Rodolfo de Oliveira Souza (Orientador: José Bueno Conti)

Esta pesquisa procura estabelecer uma relação entre as massas de ar atuantes no inverno e a precipitação nival no sul do Brasil. A área de análise foi restringida ao Planalto da Neve (definido na dissertação de mestrado) e, secundariamente, ao Planalto de Palmas, ainda sem definição. compreensão, ter uma leitura mais crítica das representações cartográficas; utilizar representações cartográficas através da análise, correlação e síntese, para uma melhor compreensão do mundo e discutir a subjetividade dos mapas temáticos e da linguagem cartográfica, a partir do mapa sintese.

Acreditamos que, assim, nosso encaminhamento valorizou o conhecimento prévio do aluno e buscou a autonomia dos educandos, proporcionando-lhes um aprendizado contínuo.

Embora essa não fosse nossa preocupação a priori, esta pesquisa pode ser considerada como uma tentativa de desenvolver as competências e habilidades que têm sido amplamente discutidas no ensino atualmente.

Para isso foi utilizada a proposta metodológica de Monteiro sobre o índice de participação das massas de ar Foi possivel classificar os anticiclones polares em três tipos: Anticiclone Polar Marítimo, Anticiclone Polar Continentalizado e Anticiclone Polar Continental.

Constatou-se, por metido de estatística não-paramétrica, que o Anticiclone Polar Continental exerce importante papel para a ocorrência de nevada e apenas secundariamente o Anticiclone Polar Continentalizado se associa à nevada. A análise rítmica permitiu confirmar e mostrou como cada um repercute sobre a superfície. Nela foi adicionada a circulação em altitude. 


\section{Parque estadual das Fontes do Ipiranga (PEFI): caracterização de nascentes numa perspectiva conservacionista}

Luiz A M. Reis

(Orientador: Lylian Coltrinari)

Este trabalho tem como objetivo caracterizar o Parque Estadual das Fontes do Ipiranga (PEFI) enquanto Unidade de Conservação localizada em uma grande metrópole e apresentar os resultados do estudo realizado nas nascentes do rio Ipiranga.

Com esse propósito, foram pesquisados tanto aspectos relacionados à delimitação e uso/ocupação das respectivas áreas quanto a caracterização do meio físico. Para tanto, foram considerados os aspectos geológicos, geomorfológicos, pedológicos, climáticos, hidrográficos, hidrogeológicos e da vegetação. Os procedimentos e a análise das informações referenciaram-se nas concepções teórico-metodológicas de Tricart e Bertrand e os princípios propostos pela geomorfologia. A coleta de dados bibliográficos e cartográficos e os

\section{Gestão Municipal e T Conservação da Natureza: a bacia hidrográfica do ribeirão das Anhumas - Campinas/SP}

Marisa Teresinha M. Frischenbruder (Orientador: Felisberto Cavalheiro)

Este trabalho se situa no campo das discussões sobre proposições e práticas de planejamento e gestão municipal trabalhos de campo para verificação e atualização das informações sobre o PEFI geraram os dados utilizados na conclusão da presente pesquisa.

Os produtos desses levantamentos permitiram a organização de mapas temáticos, que orientaram a apresentação dos resultados e sua análise, em particular no que se refere aos impactos ambientais derivados dos processos de urbanização.

Os resultados obtidos quanto aos impactos ambientais revelam intensa degradação atual, historicamente, crescente, devido ao desenvolvimento urbano local. Propõe-se que as intervenções futuras levem em conta a necessidade de monitoramento das nascentes e a necessidade do aprimoramento da educação ambiental. Quanto a possíveis intervenções, sua viabilização deve considerar os princípios do desenvolvimento sustentável, já que qualquer trabalho que considere a melhor convivência entre homem e natureza torna-se pertinente, não pela natureza em si, mas pela própria fragilidade do humano e sua (inter)dependência com seu espaço geográfico.

brasileiras, analisando-se particularmente questões relativas a condições ambientais e Conservação da Natureza. Tem como centro da análise o processo de implementação de política ambiental, na sua dimensão territorial, realizado no município de Campinas/SP no período 1993/96 e, particularmente, em 1996, quando grande parte da concepção de política de ordenamento municipal tinha já sido concretizada em leis, regulamentos e 
rotinas de trabalho no Departamento de Meio Ambiente, da Secretaria Municipal de Planejamento e Meio Ambiente, representando o conjunto mais acabado dessa concepção de política. O estudo foi realizado para uma sub-bacia hidrográfica do município, a do ribeirão das Anhumas, contribuinte do rio Atibaia, situada na porção centro - norte/noroeste de Campinas. Neste trabalho foi dada ênfase aos aspectos relacionados à Conservação da Natureza em áreas intensamente ocupadas - urbanas e rurais - e consideradas algumas estratégias que podem ser desenvolvidas pelo Poder Público Municipal. Para essa análise, além do

\section{A Chuva na Bacia do Alto Paraguai: contribuição ao estudo de aspectos das flutuações interanuais durante o século $X X$}

\author{
Luiza Luciana Salvi Sakamoto
}

(Orientador: José Roberto Tarifa)

Analisaram-se séries dos totais anuais de chuva de 11 localidades situadas na Bacia do Alto Paraguai e séries das cotas anuais do Rio Paraguai objetivando conhecer as características e tendências das flutuações da chuva ao longo do século XX. A variabilidade dos totais anuais de chuva foi estudada através do cálculo dos desvios da média dos totais anuais do segmento temporal abrangido por cada série. Para as séries mais longas, compararam-se as normais de precipitação anuais e mensais de 1931-60 e de 1961-90 e estudaram-se: a) as tendências, calculando-se as médias móveis dos totais anuais, das estações chuvosa e seca e sazonais; b) a exame dos documentos relativos à política e do traçado do percurso realizado entre as concepções e a sua concretização em práticas, técnicas e ações para implementação, foi construido um modelo cartográfico simplificado do território, procurando caracterizar a Paisagem sob gestão pública e aspectos importantes da evolução histórica de ocupação da região. Foram identificadas analogias entre os modelos trabalhados e processos de evolução de modelos, quando estes são utilizados como instrumentos de conhecimento e ação sobre a realidade e modificados, conforme esse processo evolui.

periodicidade, construindo-se periodogramas dos totais mensais; c) os extremos chuvosos e secos, realizando-se a análise de intervenção; d) a variabilidade e sucessão temporal dos desvios da normal de 1961-90 segundo a latitude para o período de 1934 a 1997; e) as enchentes e vazantes do Rio Paraguai de 1900 a 1997 Os resultados mostraram flutuações de longo período de condições tendendo a chuvosas e tendendo a seca, de duração aproximada de 30 anos, e flutuações de curto período de duração de 2 a 5 anos consecutivos. As condições chuvosas ou secas podem ter seus efeitos potencializados pela persistência presente em todas as séries e/ou pelo deslocamento segundo a latitude dos extremos chuvosos ou secos. Não foram encontradas evidências claras de mudanças climáticas. Anos secos em Corumbá coincidem com o mínimo do número de manchas solares. Eventos El Niño fortes mostraram coincidência com 
águas baixas no Rio Paraguai e eventos El Niño moderados, com águas altas que ocorrem também na ausência de eventos.

\section{Jardim Colibri- análise geográfica como subsídio para o planejamento ambiental territorial}

Isabel Cristina Moroz C. Gouveia

(Orientador: Jurandyr L. S. Ross)

Entende-se que a paisagem possui um caráter dinâmico por considerar todas as interações entre os aspectos físicos, bióticos e humanos inseridos nas dimensões espaço e tempo. Pretende-se neste trabalho desenvolver uma análise ambiental à partir dos diversos componentes da paisagem observados na área de estudo, considerando também a forma como tem ocorrido seu processo de ocupação ao longo das últimas décadas.

Nesse sentido elegeu-se como área de estudo para a elaboração da análise, o Jardim Colibri, loteamento localizado na porção Oeste da Região Metropolitana de São Paulo em área pertencente aos municípios de Embú e Cotia.

Constata-se na área um processo de ocupação em ritmo acelerado, resultando num mosaico bastante diversificado. Esse crescimento vertiginoso vem ocorrendo às custas de uma progressiva alteração do meio físico-biótico, das condições ambientais, e da qualidade de vida da população.

Assim, a presente pesquisa tem como objetivo uma avaliação do quadro ambiental da área. Esta avaliação, resultante da análise integrada dos componentes do meio físico, biótico, do processo de ocupação, das diferentes formas de uso e ocupação da terra e da legislação incidente na área, permitirá compreender a situação atual do ambiente em questão, identificando alterações ambientais resultantes de um processo de ocupação que desconsidera eventuais restrições impostas por alguns desses componentes.

Acredita-se que este produto poderá fornecer subsídios aos órgãos públicos estaduais e municipais envolvidos, no sentido de nortear o planejamento da área a fim de evitar a total degradação do ambiente, bem como na adoção de medidas que minimizem os impactos já existentes.

\section{Astronomia no ensino de Geografia}

Paulo Henrique

(Orientadora: Maria Elena Ramos Simielli)
Pesquisa acerca dos temas de Astronomia que constam nos livros didáticos de Geografia. Nos últimos anos o Ministério da Educação - MEC estabeleceu critérios para a análise de livros didáticos, 
visando melhorar a qualidade dessas obras. Foram analisados exclusivamente, os temas de Astronomia nos livros didáticos de Geografia da $5^{a}$ série recomendados pelo MEC no Plano Nacional do Livro Didático - PNLD 1999, e constatou-se grande quantidade de erros conceituais nos textos e nas ilustrações. Verificou-se que os autores de obras didáticas de Geografia têm dado considerável atenção à Astronomia, assim como os Parâmetros Curriculares do Ensino Fundamental para a Geografia do Terceiro Ciclo. As obras foram submetidas aos critérios classificatórios do MEC que permitiram o exame da qualidade desses livros quanto aos aspectos tipográficos, metodológicos, específicos de conteúdos e gerais deles e dos manuais dos professores. Os temas selecionados e avaliados estão na interface dos estudos geográficos e astronômicos, que pode ser denominada por Cosmografia, são eles: a orientação geográfica, as estações do ano, os movimentos da Terra e as marés. Os erros das obras analisadas foram apontados e corrigidos. Propôs-se que os estudos cosmográficos veiculados pelos livros didáticos empreguem termos e ilustrações corretos e adequados. São apresentadas também propostas para a confecção de modelos tridimensionais e a realização de atividades práticas, para cada um dos temas, adequadas ao nível cognitivo do Terceiro Ciclo.

\section{Interações entre Modelado e Solo no Transecto Espraiado, São Pedro, SP.}

\author{
Sheila Aparecida Correia Furquim \\ (Orientador: Lylian Coltrinari)
}

O objetivo da presente pesquisa consiste em identificar feições macro e micromorfológicas (em escala de campo e do microscópio óptico, respectivamente) e evidências analíticas (parâmetros físicos e químicos) que indiquem possíveis mecanismos de translocações, perdas e acumulações de matéria no interior da cobertura pedológica, possivelmente responsáveis pela modificação do modelado em um transecto localizado na região de São Pedro (SP).

O transecto estudado, denominado Espraiado, subdivide-se em 5 segmentos: segmento superior, segmento médio e segmentos inferiores $a, b$ e c. O segmento superior apresenta baixas declividades e presença do Neossolo Quarzarênico, solo espesso e arenoso caracterizado pela sequência vertical de horizontes $A, A E, E$ com bandas e C-1. O segmento médio apresenta declividades comparativamente médias e presença dos Argissolos Amarelo e Acinzentado, caracterizados pela espessura menor que a do Neossolo Quartzarênico e pela sequência de horizontes $A, A E, E$ com bandas, Bt, C-2 e $\mathrm{C}-3$. Os segmentos inferiores possuem as maiores declivi-dades e solos com a maior presença de argila e a menor espessura do transecto: Cambissolo Háplico, com sequência de horizontes $A, A B i, B i, C-2$ e $C-3$; e Neossolo Litólico, com sequência de horizontes $\mathrm{A}, \mathrm{C}-2$ e $\mathrm{C}-3$.

As feições identificadas, principalmente macro e micromorfológicas, indicam a ocorrência de processos 
químicos e mecânicos no interior da cobertura pedológica, desencadeado principalmente pela circulação da água no interior dos solos e responsáveis pela redistribuição e/ou remoção de material em todo o transecto. No Neossolo Quartzarênico, onde há provavelmente maior infiltração de água e dominância do fluxo interno vertical, foi encontrada maior presença das seguintes feições: bandas e interbandas, interpretadas como evidências de-iluviação de plasma; golfos nas partículas de quartzo, interpretados como evidências de dissolução de sílica; e feições relacionadas ao fenômeno de plasma infusion, o qual provoca a desintegração das partículas de areia em partículas menores. Nos Argissolos (Amarelo e Acinzentado) e no Cambissolo Háplico, onde há menor infiltração de água e provavelmente maior presença de fluxo interno lateral, estas feições aparecem em menor quantidade, mas dominam outras, tais como: bandas e interbandas, provavelmente associadas à perda de de plasma do horizonte subjacente; oríficos e concavidades superficiais provável-mente associados ao processo de piping, mosqueamentos que indicam processos de hidromorfia e, portanto, maior mobilidade

\section{Análise ambiental e cartografia geomorfológica do município de Jacutinga-MG}

\author{
Max Furrier \\ (Orientador: Jurandyr L. S. Ross)
}

Este trabalho apresenta a caracterização do meio físico e econômico do município de Jacutinga, localizado no do ferro reduzido, e feições relacionadas à mobilização de plasma e esqueleto nos macroporos. As únicas feições encontradas que indicam a deposição ou precipitação de elementos no sistema foram as bandas do Neossolo Quartzarênico (as quais indicam simultaneamente perda de matéria), e as denominadas "superfícies duplas" das partículas de quartzo.

Desta forma, parece que a cobertura pedológica do transecto Espraiado caracteriza-se principalmente pela perda generalizada de matéria, provavelmente associada a uma perda de volume dos solos e a um rebaixamento do modelado local, assim como descrito em outras áreas tropicais. Assim, os resultados apresentados estão em desacordo com a idéia de oposição entre os processos pedogenéticos e morfogenéticos, comumente presente na visão tradicional das relações solo-relevo, uma vez que os processos deduzidos são possivelmente responsáveis não apenas por mudanças de características morfológicas da cobertura pedológica, mas também por mudanças no modelado. Além disto, a presença destes processos na área estudada parece estar de acordo com os princípios da teoria de etchplanação.

extremo sul do estado de Minas Gerais, além de um estudo integrado do meio ambiente, onde o relevo é o alicerce da pesquisa. Embora o foco principal esteja embasado no relevo, sua análise e caracterização foi apoiada pelos demais componentes do meio físico como a geologia, os solos, a vegetação, o clima e a própria sociedade. Concomitantemente a essa caracterização foram elaborados e 
confeccionados mapas temáticos sobre a geomorfologia, pluviometria e uso e ocupação da terra.

O mapeamento geomorfológico foi elaborado com base na metodologia proposta por ROSS (1992) que, devido à escala definida no trabalho (1:50.000), foi detalhado até o quarto táxon caracterizado pelos Índices de Dissecação do Relevo.

O produto final do presente trabalho foi sintetizado no mapa de fragilidade do relevo, elaborado com base na metodologia proposta por ROSS (1994), que consistiu na sobreposição das informações

\section{- A Cartografia Temática no Ensino Médio de Geografia: A Relevância da Representação Gráfica do Relevo}

\author{
Clézio Santos \\ (Orientador:Marcelo Martinelli)
}

A Cartografia e a Geografia estão diretamente presentes na sociedade tanto no dia-a-dia como em setores específicos. A escola é um desses locais cuja presença desses conhecimentos são importantes na tarefa de formar e informar nossos cidadãos. O ambiente escolar nos faz refletir enquanto pesquisadores o comprometimento social que temos, em trabalhar as diversas realidades presentes no cotidiano dos alunos.

As seguintes indagações guiaram nosso trabalho: O despreparo em relação aos conhecimentos de representação gráfica e cartográfica tem origem na contidas nos mapas temáticos produzidos e nos dados coletados em campo e gabinete. Esse mapa subsidiou a análise do atual estado em que se encontra o meio físico do município, identificando ambientes em função de seus diferentes niveis de intervenção humana e fragilidade. Este documento, além de sintetizar as várias informações coletadas e produzidas ao longo da pesquisa, poderá vir a ser utilizado no direcionamento adequado dos tipos de inserção no campo, além de servir como ferramenta base para futuros planejamentos territorial e ambiental.

formação do profissional em Geografia? C desinteresse em relação à representaçãc gráfica e cartográfica está preso a nãc cobrança dos programas escolares nc Ensino Médio? e Quais os principais recursos didáticos utilizados pela Geografic no Ensino Médio? Essas indagações atreladas ao nosso objetivo - avaliar comc a realidade relevo é representadí graficamente e cartograficamente nos Livros Didáticos de Geografia no Ensinc Médio - nos conduziram em nossa pesquisa.

Pretendemos com nossa pesquisa, oferecer aos professores e alunos de Geografia do Ensino Médio alternativas de trabalho da realidade relevo em sala de aula, por meio da representação gráfica e cartográfica. Colaborando para divulgar a relevância da Cartografia no processo de ensino-aprendizagem de Geografia no Ensino Médio, e ressaltando a necessidade da linguagem visual nesse período escolar. 


\section{A Construção Coletiva do de Aula}

\section{Ana Maria Mastrangelo}

(Orientador: Regina Araújo de Almeida)

Esta Dissertação de Mestrado é o resultado de um grande esforço para elaborar uma proposta de abordagem didática, com o objetivo de trabalhar os seguintes Elementos da Linguagem Gráfica em Cartografia: Escala, Proporção, Orientação, Visão Vertical e Oblíqua, a partir de um Tema, com alunos do 10 Termo do Ensino Supletivo, do Ensino Fundamental, do período Noturno de uma Escola Pública Municipal de São Paulo, considerando-se as condições de trabalho reais do dia-a-dia do professor.

O trabalho de pesquisa foi realizado durante o expediente normal das aulas, envolvendo a rotina diária da Escola, da classe em questão, seus problemas, suas dificuldades, seu calendário etc, o que exigiu também da professora a tarefa de observação e registro do que foi possível, do próprio trabalho.

O tema escolhido foi: A Desigualdade Social na Cidade de São Paulo, sob o ponto de vista da moradia, emprego e qualidade de vida.

À medida que o tema se desenvolveu, sob questionamentos, análises de imagens, produção de textos do aluno, leitura e entendimento de textos de jornais, observação de mapas e tabelas de jornais, textos sínteses envolvendo conceitos próprios da Geografia como paisagem, lugares próximos ou distantes em diferentes escalas, o aluno foi tomando conhecimento, dos elementos e habilidades próprias da Cartografia, chegando à leitura de mapas e à construção de croquis simplificados.

Na verdade, o trabalho desencadeou um processo de alfabetização como um todo. O aluno de Suplência, geralmente, tem facilidade em Matemática, mas dificuldades em leitura e entendimento de textos. Foi preciso trabalhar a Alfabetização Cartográfica, Geográfica e Lingüística como um todo. Foi preciso construir os conceitos, num trabalho coletivo, seja em dupla ou em trio, para que, nessa interação com o outro, o aluno ultrapassasse suas dificuldades. Seria muito bom se houvesse continuidade desta construção de conceitos nos Termos seguintes. Mas, como sabemos, a próxima turma do professor, geralmente, é nova, não conhece os elementos básicos para a leitura de mapas. Sendo assim, esta proposta poderia ser vista como um conjunto "necessário" de elementos e situações de domínio do professor que possibilitem ao aluno chegar à leitura de mapas, independente do tema, da série, do conteúdo.

O conhecimento dos elementos da Linguagem Gráfica pode ter início com a leitura do caminho casa-trabalho-escola, chegando-se até à leitura das curvas de nivel do local onde está a Escola e seus arredores.

O fato é que, ter conhecimento dos Elementos da Linguagem Gráfica Cartográfica é fundamental para o usuário de mapas, nos dias de hoje. Independente de ter ou não formação em Cartografia, o usuário precisa ler com desenvoltura os símbolos e signos dos guias de ruas, mapas turísticos croquis de imobiliárias etc, orientando-se espacial e mentalmente diante de um mapa, com uma possivel visão crítica, do espaço em questão. 
Neste sentido, as novas tecnologias e a informatização na produção desses produtos cartográficos avança rapidamente o que já não acontece com o domínio da leitura informatizada pela maioria da população. Sabe-se que, no momento, apenas cerca de $7 \%$ da população brasileira tem acesso e consegue ler a linguagem da Informática.

O Embasamento Teórico da pesquisa conta com um número mínimo de teóricos da Cartografia como Meio de Comunicação e Informação no Ensino de Geografia.

Inicialmente apresentamos definições, evolução histórica e tendências atuais da Cartografia. Em seguida damos destaque aos Modelos de Comunicação Cartográfica das décadas de 70 e 90, selecionando pesquisadores como: Board e Kolacny na Teoria da Informação; Bertin na Semiologia Gráfica; Robinson e Petchenik na Teoria da Cognição; DiBiase, MacEachren e Taylor na Teoria da Informática.

Por fim destacamos a pesquisa de M.E. Simielli na Alfabetização Cartográfica e o Ensino de Geografia.

Quanto à Metodologia, a $1^{\text {a }}$ parte envolve o processo de trabalho em sala de

\section{A conservação da vegetação dos cerrados em são Paulo: estudo de caso na região do Médio Paranapanema}

\author{
Renata Ramos Mendonça \\ (Orientadora: Iraci Palheta)
}

A vegetação dos cerrados no estado de São Paulo está se extinguindo; dos $18 \%$ que originalmente cobriam o aula e a relação professor $x$ aluno; a construção de um cronograma para se chegar à construção do croqui em sala de aula e à Geografia que se pretende.

Isto envolveu a elaboração e prática de nove Planos de Aulas, num trabalho que se ampliou do próximo para o distante, questionando-se em classe 0 significado desse próximo e distante do aluno. Nesses Planos de aula trabalhamos - caminho casa-trabalho-escola, orientação, maquete, uso da bússola, planta dos arredores da Escola, do Município de São Paulo, da Grande São Paulo, sob o ângulo da desigualdade social da cidade, chegando à construção do croqui coletivo.

$\mathrm{Na} 2^{\mathrm{a}}$ parte registramos o resultado do processo, analisando os resultados das observações quanto aos Planos de Aulas, objetivos propostos e retorno à realidade des/Integrada e entendemos que 0 professor precisa ter esse conhecimento mínimo da Cartografia, essa visão de conjunto, do todo, trabalhando-a sempre que houver necessidade dentro dos oito anos do Ensino Fundamental instrumentalizando o aluno na Alfabetização como um todo e desmistificando a Cartografia Desenho.

território paulista, hoje só resta cerca de $1 \%$ espalhado por inúmeros pequenos fragmentos. Menos de $10 \%$ do que restou dessa vegetação estão inseridos nas unidades de conservação estaduais e, grande parte do restante, localiza-se em propriedades rurais particulares. Como não existe nenhuma legislação específica para conservação desse tipo de vegetação, sua proteção fica restrita às diversas leis e decretos federais esparsos, que têm como 
instrumento efetivo de conservação as unidades de conservação e as reservas legais. Por meio de uma análise das características ecológicas desse domínio e do uso e ocupação dessas áreas e as do restante do país, chegou-se a conclusão que estas sempre foram consideradas áreas de fronteiras agrícolas, tendo como modelo econômico as grandes propriedades e produção para exportação. $\mathrm{Na}$ área de estudo, no Médio Paranapanema, onde ainda existem os maiores fragmentos de cerrados da região, verificou-se a presença de grandes propriedades tendo como atividade econômica mais importante a pecuária. Esses fragmentos ainda existem por serem, na maioria das vezes, as reservas legais dessas propriedades. Verificou-se uma relação conflituosa entre os proprietários e esta vegetação, associada ao enorme desconhecimento dos benefícios que ela pode trazer e pouco interesse na sua conservação. A conservação desses fragmentos só está ocorrendo por constituirem as reservas legais das propriedades rurais, ou seja apenas pela força da lei. 